\title{
ANALISIS FAKTOR-FAKTOR PENENTU DALAM PENINGKATAN KONDISI SOSIAL EKONOMI PETANI HUTAN RAKYAT DI KABUPATEN CIAMIS
}

\author{
An analysis of key factors in improving the social economic condition \\ of private forest in Ciamis District \\ Budiman Achmad ${ }^{1)}$, Dian Diniyati ${ }^{2)}$, Eva Fauziyah ${ }^{3)}$ dan/and Tri Sulistyati $\mathbf{W}^{4)}$ \\ Balai Penelitian Teknologi Agroforestry \\ Jl. Raya Ciamis Banjar Km 4 Desa pamalayan Ciamis 46201 \\ Telp. 0265-771352 , Fax.0265-775866 \\ E-mail : ${ }^{1)}$ budah59@yahoo.com; ${ }^{2}$ dian_diniyati@yahoo.com; ${ }^{3)}$ eva_fauziyah@yahoo.com; ${ }^{4)}$ dlist23@yahoo.com
}

Naskah masuk : 22 April 2014; Naskah diterima : 17 Maret 2015

\begin{abstract}
The research aims to identify socio-economic conditions of the farmers influencing private forest development and to identify factors improving their socio-economic condition. The research was conducted on May to July 2010 in Ciomas, Kalijaya and Kertaharja Villages of Ciamis District. Data were collected by interviewing sixty selected respondents and also analysed using descriptive qualitative namely age, education, family size, resident stay, total income and land size. The result showed that farmer were dominated by moderate and old ages with education level of equivalent to the first and second grades of junior high school. Farmers incomes in Kalijaya and Kertaharja were mostly from the forests, while in Ciomas was from service sectors. Their incomes in Ciomas were unequally distributed, while in Kalijaya and Kertaharja were moderates equality distributed. Education level inproved significantly economic conditions in Ciomas while the improved factors in Kertaharja and Kalijaya were education level and family size.
\end{abstract}

Keywords: Private forest, socio-economic condition, farmers, income distribution

\begin{abstract}
ABSTRAK
Penelitian ini bertujuan untuk mengetahui kondisi sosial ekonomi petani yang mempengaruhi perkembangan hutan rakyat dan untuk mengetahui faktor-faktor yang dapat meningkatkan kondisi sosial ekonomi petani. Penelitian ini dilaksanakan pada bulan Mei sampai dengan Juli 2010 di Desa Ciomas, Kalijaya dan Kertaharja, Kabupaten Ciamis. Data dikumpulkan dengan teknik wawancara terhadap enam puluh responden yang dipilih secara sengaja, kemudian ditabulasikan dan dianalisa secara diskriptif kualitatif. Faktor yang mempengaruhi sosial ekonomi petani terdiri atas umu, pendidikan, ukuran keluarga, status kependudukan, penghasilan dan kepemilikan lahan. Hasil penelitian menunjukkan bahwa umur petani didominasi oleh umur produktif menengah dan tua (40 sampai dengan 59 tahun) dengan tingkat pendidikan setara kelas 1 sampai dengan 2 SMP. Pendapatan petani di Desa Kalijaya dan Desa Kertaharja mayoritas berasal dari usaha hutan rakyat, sementara itu pendapatan petani di Desa Ciomas mayoritas berasal dari sektor jasa. Pendapatan petani di Ciomas menyebar tidak merata, sedangkan di Kalijaya dan Kertaharja terdistribusi cukup merata. Faktor-faktor yang secara nyata mempengaruhi peningkatan kondisi sosial ekonomi petani di Ciomas adalah tingkat pendidikan, sedangkan di Kertaharja dan Kalijaya adalah tingkat pendidikan dan jumlah anggota keluarga.
\end{abstract}

Kata kunci: Hutan rakyat, kondisi sosial ekonomi, petani, sebaran pendapatan.

\section{PENDAhULUAN}

Kondisi sosial ekonomi suatu kelompok masyarakat sangat penting untuk diketahui jika kelompok tersebut akan ditingkatkan kondisi ekonominya melalui kegiatan pembangunan. Berdasarkan berbagai kajian yang telah dilakukan di beberapa wilayah Indonesia dihasilkan bahwa kondisi sosial ekonomi dapat dijadikan sebagai bahan pertimbangan bagi para pembuat kebija-kan yang berkaitan dengan perbaikan lingkungan (Haryanti et al., 2005; Mairi, 2005; Dewi \& Iwanuddin, 2005; Irawanti, 2006; Sanudin \& Bambang, 2007). 
Kegiatan pembangunan hutan rakyat dipengaruhi oleh faktor internal dan eksternal yang dimiliki oleh petani sebagai pemilik dan pengelolanya. Faktor internal adalah faktor yang melekat atau dimiliki oleh petani dan keluarganya diantarnya: tingkat pendidikan, jumlah anggota keluarga, jenis pekerjaan dan kepemilikan lahan. Sedangkan faktor eksternal terdiri dari berbagai kebijakan yang dilakukan oleh pemerintah, sarana dan prasarana pendukung pembangunan hutan rakyat. Kondisi sosial ekonomi petani merupakan kedudukan atau posisi petani di dalam masyarakat berkaitan dengan faktor internal atau tingkat pendidikan, jenis pekerjaan, jumlah anggota keluarga dan pemilikan lahan.

Hutan rakyat di Kabupaten Ciamis tersebar di seluruh kecamatan yang dikelompokkan menjadi 3 (tiga) wilayah pengembangan, yaitu pengembangan utara, tengah dan selatan. Wilayah pengembangan utara mewakili wilayah pegunungan, pengembangan tengah mewakili wilayah perkotaan dan pengembangan selatan mewakili daerah pantai. Faktor internal maupun eksternal akan mempengaruhi keputusan petani dalam pengembangan hutan rakyatnya. Namun tidak semua unsur faktor tersebut, terutama faktor internal dimiliki oleh semua petani. Faktor internal akan berlainan antar daerah utara, tengah dan selatan. Hal ini berdampak terhadap pengembangan hutan rakyatnya, karena disesuaikan dengan kondisi sosial ekonomi yang berkembang di masyarakat, seperti disampaikan oleh Haryanti et al. (2005) bahwa perubahan yang terjadi pada suatu lingkungan DAS akan berpengaruh pada kondisi alam serta lingkungan sosial dan budaya masyarakatnya. Sebagai contoh perkembangan jumlah penduduk, perubahan pola pemanfaatan lahan untuk industri dan perumahan, kegiatan pertanian intensif, pemilihan jenis tanaman yang ditanam, serta berbagai interfensi kegiatan manusia terhadap lahan, mengakibatkan perubahan keadaan ekosistem dan mempengaruhi kondisi sosial masyarakatnya.

Terdapat perbedaan pengelolaan hutan rakyat di setiap wilayah pengembangan Kabupaten Ciamis, walaupun pada beberapa hal memiliki kesamaan. Perbedaan tersebut salah satunya dipengaruhi oleh faktor kondisi sosial ekonomi petaninya. Oleh karena itu perumusan kebijakan yang berkaitan dengan pengembangan hutan rakyat di setiap lokasi pengembangan perlu memperhatikan kondisi sosial ekonomi petani- nya. Supriadi \& Saliem (2006) menyatakan bahwa kebijakan pemerintah (pusat maupun daerah) secara langsung maupun tidak langsung bisa memperbaiki ataupun memperlemah kondisi sosial ekonomi masyarakat. Faktor internal berkorelasi logis dengan status sosial ekonomi dan bersifat dinamis sehingga diyakini bisa dimanipulasi untuk meningkatkan kondisi sosilekonomi petani. Sehubungan dengan hal itu, penelitian ini ditujukan untuk: 1) mengetahui kondisi sosial dan ekonomi petani hutan rakyat yang dapat mempengaruhi perkembangan pembangunan hutan rakyat di Kabupaten Ciamis, dan 2) mengetahui faktor-faktor yang dapat meningkat-kan kondisi sosial ekonomi petaninya.

\section{METODOLOGI}

\section{A. Alur Pikir Penelitian}

Pengembangan hutan rakyat sangat dipengaruhi oleh kondisi sosial ekonomi petani pemiliknya, yang dicirikan melalui: tingkat pendidikan, jumlah anggota keluarga, jenis pekerjaan dan kepemilikan lahan. Kondisi sosial ekonomi ini memberikan ciri karakteristik petani sebagai pengelola hutan rakyat. Karakteristik ini juga dipengaruhi oleh tempat dan lingkungan dimana petani tersebut berdomisili. Haryanti et al. (2005) menyatakan bahwa perubahan yang terjadi pada suatu lingkungan DAS akan berpengaruh pada kondisi alam serta lingkungan sosial dan budaya masyarakatnya. Dengan demikian pola tanam hutan rakyat di setiap lokasi penelitian juga akan berlainan dan memiliki ciri yang khas, walaupun pada beberapa aspek memiliki kesamaan. Salah satu hal yang membedakan adalah jenis tanaman yang dikembangkan setiap lokasinya.

Pengetahuan tentang karakteristik petani akan memudahkan dalam melakukan pembinaan terhadap petani. Kajian ini dilakukan melalui pengamatan langsung, dan diharapkan akan memberikan gambaran secara mendalam tentang kondisi sosial ekonomi petani pemilik hutan rakyat. Informasi yang dihasilkan dari kajian ini diharapkan dijadikan rujukan bagi pembuat kebijakan dalam penentuan program yang melibatkan petani, agar program yang akan diluncurkan dapat memperhatikan aspek lingkungan dimana petani berdomisili. Alur pikir penelitian diperlihatkan pada Gambar 1 berikut. 


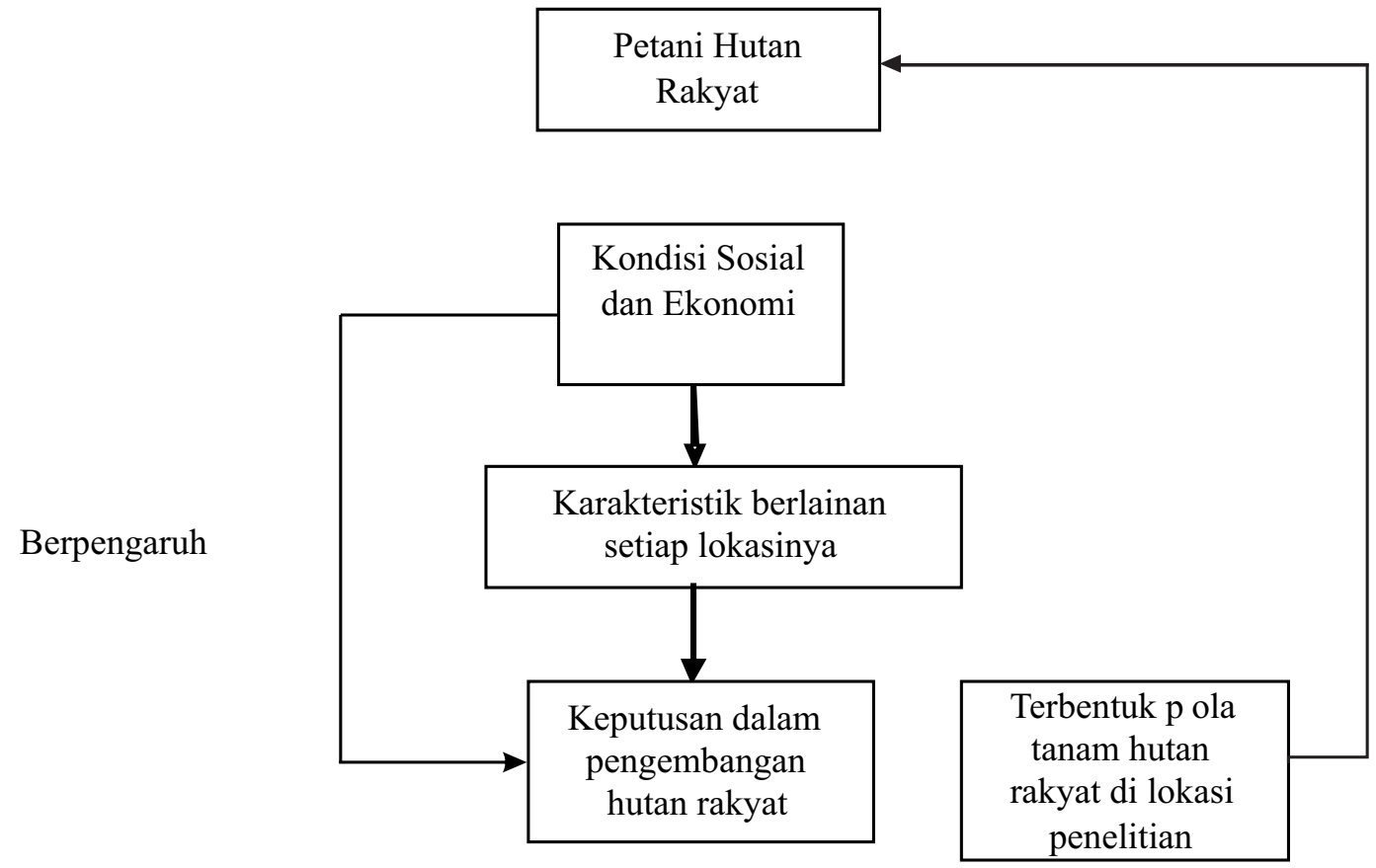

Gambar(Figure) 1. Alur pikir kondisi sosial ekonomi petani hutan rakyat di Kabupaten Ciamis (Flow of thinking of socio-economic condition of community forest farmer in Ciamis District)

\section{B. Lokasi dan Waktu Penelitian}

Kegiatan penelitian dilaksanakan pada Bulan Mei s/d Juli 2010 di Desa Ciomas Kecamatan Panjalu, Desa Kalijaya Kecamatan Banjarsari dan Desa Kertaharja Kecamatan Cimerak, Kabupaten Ciamis, Provinsi Jawa Barat.

\section{Metode Pengambilan Contoh}

Lokasi penelitian sebanyak tiga desa dipilih secara sengaja yang merupakan perwakilan wilayah pembangunan di Kabupaten Ciamis, ya-itu Desa Ciomas Kecamatan Panjalu mewakili wilayah pengembangan Ciamis bagian utara, De-sa Kalijaya Kecamatan Banjarsari mewakili wilayah pengembangan Ciamis bagian tengah, dan Desa Kertaharja Kecamatan Cimerak me-wakili wilayah pengembangan Ciamis bagian se-latan.

Responden pada penelitian ini adalah petani hutan rakyat yang tergabung dalam kelompok tani, dipilih secara sengaja (purposived). Jumlah Responden setiap desa dipilih sebanyak 20 orang sehingga total responden 60 orang.

Data yang diperlukan dalam kegiatan penelitian ini terdiri dari data primer dan sekunder. Data primer dikumpulkan secara langsung dari nara sumber yaitu petani hutan rakyat dengan cara wawancara menggunakan kuisioner yang telah dipersiapkan terlebih dahulu. Data sekunder berupa data yang sudah disajikan dalam laporanlaporan instansi yang terkait dengan kegiatan penelitian, diantaranya adalah laporan dari Dinas Kehutanan dan Perkebunan Kabupaten Ciamis, Kantor Desa, dan Laporan Badan Pusat Statistik Kabupaten Ciamis.

\section{Analisa Data}

Data primer dan sekunder yang telah terkumpul selanjutnya ditabulasikan dan dikelompokkan sesuai dengan tujuan penelitian, kemudian dianalisis menggunakan Metode Analisis Kesejahteraan: meliputi Analisis Gender, Analisis Pendapatan Rumah Tangga, Analisis Koefisien Gini, dan Analisis Garis Kemiskinan, yang secara kualitatif dan kuantitatif menggambarkan kondisi sosial dan ekonomi responden petani hu$\tan$ rakyat di tiga wilayah pengembangan. Sedangkan untuk mengetahui faktor-faktor penentu dalam peningkatkan kondisi sosial ekonomi dilakukan dengan menggunakan uji Chi-Square.

Kriteria koefisien Gini (KG) yang digunakan seperti yang tercantum dalam Badan Litbang Kehutanan dan Perkebunan (2000), yaitu:

$\mathrm{KG}<0,4 \quad$ : tingkat ketimpangan rendah

$\mathrm{KG} 0,4 \quad 0,5$ : tingkat ketimpangan moderat $\mathrm{KG}>0,5 \quad$ : tngkat ketimpangan tinggi. 


\section{HASIL DAN PEMBAHASAN}

\section{A. Pengaruh Kondisi Sosial Ekonomi Petani terhadap Perkembangan Hutan Rakyat}

Petani hutan rakyat yang tergabung dalam kelompok tani memiliki kondisi sosial dan ekonomi tersendiri, yang mencirikan karakter petaninya sehingga dapat dibedakan antara petani yang tinggal di wilayah utara, tengah dan selatan. Perbedaan karakter ini juga didukung oleh kondisi lingkungan dimana petani tersebut tinggal. Kondisi sosial dan ekonomi yang akan dibahas meliputi: umur, jenis kelamin, pendidikan, sifat kependudukan yang ditentukan oleh lama tinggal di desa, jumlah tanggungan keluarga, jenis pekerjaan serta status di desa, seperti diuraikan berikut ini.

\section{Umur responden}

Berdasarkan hasil olahan data diketahui bahwa responden termasuk dalam golongan umur produktif yaitu antara umur 20-59 tahun. Hal tersebut menunjukkan bahwa pengelolaan hutan rakyat di seluruh lokasi penelitian dilakukan oleh petani yang tergolong umur produktif usia menengah dan tua, hal ini sejalan dengan hasil penelitian yang dilakukan oleh Susilowati \& Suhaeti, (2012). Umur yang ma-sih produktif ini menunjukkan bahwa secara fisik sangat potensial untuk pengembangan hutan rakyat. Menurut Fatati (2001) dalam Saniet et al. (2010) bahwa semakin muda umur seseorang maka semakin mudah menerima perubahan dari luar karena petani selalu ingin mencoba sesuatu yang baru sebagai upaya meningkatkan pengetahuan dan keterampilan dalam diver-sifikasi usahanya. Jadi pada umur produktif ini biasanya petani dapat menghasilkan inovasiinovasi baru serta mau menerima teknologi sehingga dapat meningkatkan pengembangan hutan rakyat di wilayahnya. Data umur responden diperlihatkan oleh Gambar 2 di bawah ini.

Responden di Desa Kertaharja dan Kalijaya seluruhnya berjenis kelamin laki-laki. Sementara itu di Desa Ciomas ada tiga orang responden yang berjenis kelamin perempuan yang termasuk pada kelompok umur produktif. Kondisi jenis kelamin responden seperti disajikan oleh Tabel 1. Adanya responden perempuan menunjukkan bahwa bidang usaha hutan rakyat juga menarik bagi perempuan. Komoditas kapulaga dan jasa tergolong pada bidang usaha dimana perempuan mampu berpartisipasi. Ada banyak alasan yang dikemukakan oleh responden perempuan dalam keterlibatannya di hutan rakyat, diantaranya bahwa suami sudah meninggal dan tidak ada lagi tenaga kerja yang dapat mengurus usaha hutan rakyat yang dimilikinya, tidak ada lagi usaha lainnya yang dapat dilakukan, serta hasil ekonomi dari hutan rakyat dapat memenuhi ke-

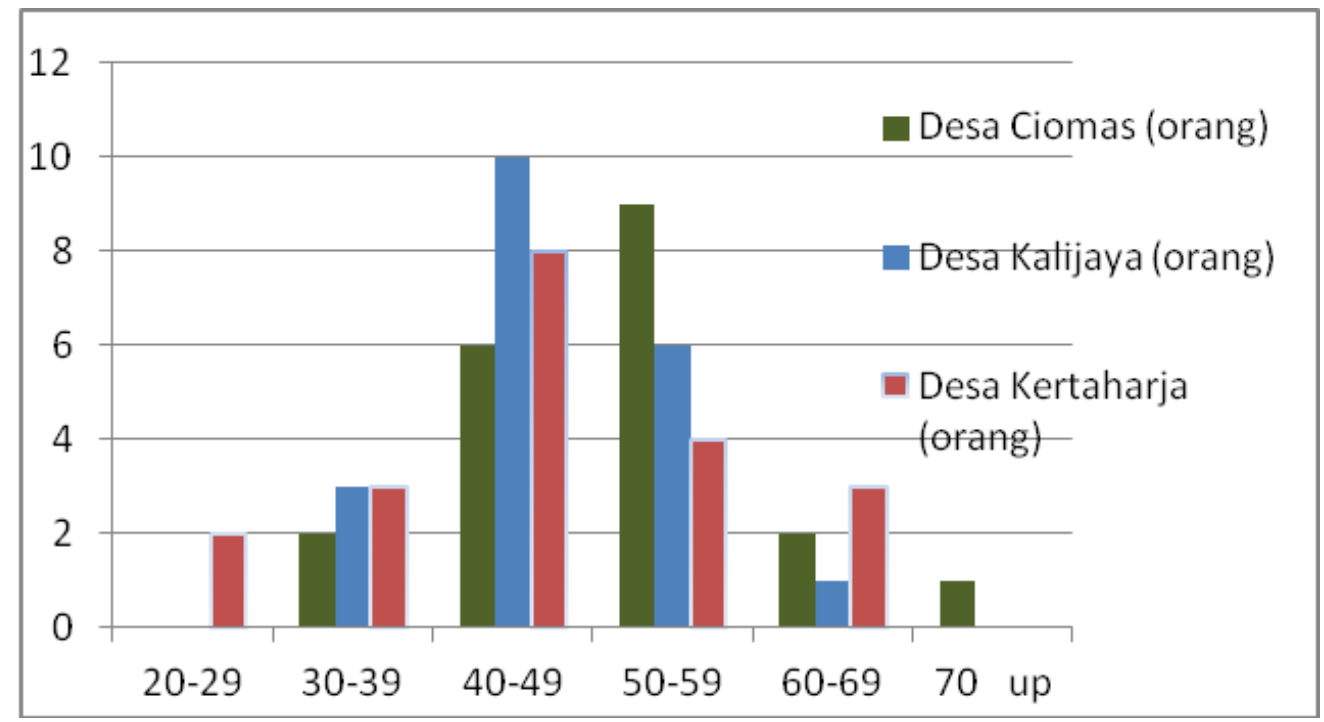

Gambar (Figure) 2. Rata-rata umur responden petani di lokasi penelitian (The average of respondent ages at research locations) 
Tabel (Table) 1. Kondisi jenis kelamin responden (Gender condition of respondents)

\begin{tabular}{ccccccc}
\hline \multirow{2}{*}{$\begin{array}{c}\text { Kelompok } \\
\text { umur (Thn) } \\
\begin{array}{c}\text { Age group } \\
\text { (Year) }\end{array}\end{array}$} & \multicolumn{2}{c}{ Desa (Village) Ciomas } & \multicolumn{2}{c}{ Desa (Village) Kalijaya } & \multicolumn{2}{c}{ Desa (Village) Kertaharja } \\
\cline { 2 - 7 } & $\begin{array}{c}\text { Laki- } \\
\text { Laki } \\
\text { (Male) })\end{array}$ & $\begin{array}{c}\text { Perempuan } \\
\text { (Female) }\end{array}$ & $\begin{array}{c}\text { Laki-laki } \\
\text { (Male) }\end{array}$ & $\begin{array}{c}\text { Perempuan } \\
\text { (Female) }\end{array}$ & $\begin{array}{c}\text { Laki-Laki } \\
\text { (Male) }\end{array}$ & $\begin{array}{c}\text { Perempuan } \\
\text { (Female) }\end{array}$ \\
\hline $20-29$ & 0 & 0 & 0 & 0 & 2 & 0 \\
$30-39$ & 2 & 0 & 3 & 0 & 3 & 0 \\
$40-49$ & 6 & 0 & 10 & 0 & 8 & 0 \\
$50-59$ & 6 & 3 & 6 & 0 & 4 & 0 \\
$60-69$ & 2 & 0 & 1 & 0 & 3 & 0 \\
70 up & 1 & 0 & 0 & 0 & 0 & 0 \\
\hline Total & 17 & 3 & 20 & 0 & 20 & \\
\hline
\end{tabular}

Sumber: diolah dari data primer, 2010 (Sources: processed from the primary data, 2010)

butuhan keluarga.

\section{Pendidikan responden}

Responden di lokasi penelitian pernah mengenyam pendidikan formal. Rata-rata responden bersekolah selama 7-8 tahun atau setara dengan SMP kelas 1 atau 2. Hal ini menunjukkan bahwa seluruh responden mampu membaca dan menulis huruf latin. Tingkat pendidikan responden tertinggi ada di Desa Kalijaya yaitu selama 18 tahun atau setara dengan sarjana. Tingkat pendidikan yang tinggi ini dimiliki oleh responden pada kelompok umur 60-69 tahun. Kondisi ini menunjukkan bahwa pekerjaan di hutan rakyat tidak hanya diminati oleh petani yang berpendidikan rendah, kenyataannya petani yang berpendidikan sarjana mau berusaha dibidang hutan rakyat. Ketertarikan reponden yang berpendidikan tinggi pada pengelolaan hutan rakyat lebih disebabkan karena faktor mobilitas. Pada usia tua, responden lebih memilih pekerjaan yang mudah dijangkau dan tidak membutuhkan tenaga besar, yaitu mengelola hutan rakyat. Lebih jauh diketahui bahwa responden yang tergolong produktif usia muda sampai menengah (berkisar 20- 49 tahun) memiliki tingkat pendidikan ratarata 8 tahun (setara SMP kelas 2), dan justru pada usia ini jumlah responden di seluruh lokasi penelitian paling banyak. Kondisi tingkat pendidikan

Tabel(Table) 2. Komposisi tingkat pendidikan responden(Level composition of respondent education)

\begin{tabular}{|c|c|c|c|c|c|c|c|}
\hline \multirow[b]{2}{*}{$\begin{array}{l}\text { Kelompok } \\
\text { Umur } \\
\text { (Thn) } \\
\text { (Age } \\
\text { Group } \\
\text { (Year) }\end{array}$} & \multicolumn{2}{|c|}{ Desa (Village) Ciomas } & \multicolumn{2}{|c|}{ Desa (Village) Kalijaya } & \multicolumn{2}{|c|}{ Desa (Village) Kertaharja } & \multirow[b]{2}{*}{$\begin{array}{l}\text { Jumlah } \\
\text { responden } \\
\text { tiap klas } \\
\text { Umur } \\
\text { (Total of } \\
\text { respondents } \\
\text { each age clas }\end{array}$} \\
\hline & $\begin{array}{l}\text { Jumlah } \\
\text { responden } \\
\text { (org) } \\
\text { (Total of } \\
\text { respondents } \\
\text { (person) }\end{array}$ & $\begin{array}{l}\text { Lama } \\
\text { pendidikan } \\
\text { (thn) } \\
\text { (Lorg of } \\
\text { education } \\
\text { (year) }\end{array}$ & $\begin{array}{l}\text { Jumlah } \\
\text { responden } \\
\text { (org) } \\
\text { (Total of } \\
\text { respondents } \\
\text { (person) }\end{array}$ & $\begin{array}{l}\text { Lama } \\
\text { pendidikan } \\
\text { (thn) } \\
\text { (Long of } \\
\text { education } \\
\text { (year) }\end{array}$ & $\begin{array}{l}\text { Jumlah } \\
\text { responden } \\
\text { (org) } \\
\text { (Total of } \\
\text { respondents } \\
\text { (person) }\end{array}$ & $\begin{array}{l}\text { Lama } \\
\text { pendidikan } \\
\text { (thn) } \\
\text { (Lorg of } \\
\text { education } \\
\text { (year) }\end{array}$ & \\
\hline $20-29$ & 0 & 0 & 0 & 0 & 2 & 9 & 2 \\
\hline $30-39$ & 2 & 9 & 3 & 6 & 3 & 8 & 8 \\
\hline $40-49$ & 6 & 7 & 10 & 9 & 8 & 7 & 24 \\
\hline $50-59$ & 9 & 5 & 6 & 8 & 4 & 6 & 19 \\
\hline $60-69$ & 2 & 9 & 1 & 18 & 3 & 6 & 6 \\
\hline 70 up & 1 & 2 & 0 & 0 & 0 & 0 & 1 \\
\hline Jumlah & 20 & & 20 & & 20 & & 60 \\
\hline
\end{tabular}

Sumber: diolah dari data primer 2010 (Sources: processed from the primary data, 2010) 
responden diperlihatkan oleh Tabel 2 berikut ini.

Kelimpahan jumlah tenaga kerja usia produktif muda (kelompok umur 40-49 tahun) menunjukkan bahwa ada jaminan bahwa hutan rakyat akan dikelola oleh tenaga kerja yang masih kuat secara fisik. Selain itu ketersediaan tenaga kerja yang berpendidikan setara sarjana bisa menjadi sumber rujukan bagi tenaga usia muda. Berdasarkan kondisi tersebut, perkembangan hutan rakyat menjadi lebih baik peluangnya besar.

\section{Jenis Pekerjaan Responden}

Tujuan utama dari berbagai usaha yang dilakukan responden adalah untuk menghasilkan

Keseluruhan responden di lokasi penelitian tidak hanya mengandalkan penghasilan dari lahan pertanian saja yang terlihat dari beragamnya jenis pekerjaan utama dan pekerjaan sampingan responden. Akan tetapi sebagian besar responden beranggapan bahwa bertani menjadi pekerjaan utama yaitu sebanyak 12 di Desa Ciomas, 13 orang di Desa Kalijaya dan 15 orang di Desa Kertaharja. Dari sebanyak 20 orang res-ponden, yang mengaku bahwa bertani hanyalah pekerjaan sampingan adalah sebanyak 8 orang di Desa Ciomas, 7 orang di Desa Kalijaya dan 5 orang di Desa Kertaharja. Jenis pekerjaan respon-den yang paling beragam terdapat di Desa Kalijaya dan Ciomas yaitu 8 jenis. Hal ini menunjukkan pendapatan supaya bisa memenuhi kebutuhan ekonomi responden dan keluarga. Usaha yang memberikan pendapatan paling besar dan dihasilkan secara rutin biasanya akan menjadi pekerjaan utama responden, sedangkan sumber pendapatan yang lainnya dijadikan sebagai pekerjaan sampingan.

Dari hasil wawancara diketahui bahwa responden memiliki pekerjaan utama dan sampingan. Pekerjaan utama sebagian besar responden adalah sebagai petani baik itu petani di lahan tegalan maupun di sawah. Secara lebih rinci, jenis pekerjaan yang dilakukan responden seperti diperlihatkan Tabel 3 .

bahwa petani terus berusaha disegala cabang usaha dan tidak hanya terpaku pada pekerjaan yang umum dilakukan oleh petani di desa. Dengan demikian, petani di Desa Kalijaya dan Ciomas dapat digolongkan sebagai petani yang kreatif, karena tidak hanya mengan-dalkan penghasilan dari pertanian saja tetapi juga dari usaha lainnya. Beragamnya pe-kerjaan pe-tani di Ciomas dan Kalijaya menye-babkan eko-nomi respoden semakin kuat. Dam-paknya ada-lah potensi modal untuk pengem-bangan hutan rakyat juga semakin besar.

Jenis pekerjaan yang paling sedikit dilakukan oleh responden adalah di Desa Kertaharja yaitu 5 jenis pekerjaan. Petani di desa ini lebih senang

Tabel(Tabel) 3. Jenis pekerjaan responden di lokasi penelitian (Kind of respondent jobs at research locations)

\begin{tabular}{llrrrrrr}
\hline \multirow{2}{*}{$\begin{array}{c}\text { No } \\
\text { (No) }\end{array}$} & \multicolumn{1}{c}{$\begin{array}{c}\text { Uraian } \\
\text { (Discription) }\end{array}$} & $\begin{array}{c}\text { Desa } \\
\text { (Village) } \\
\text { Ciomas }\end{array}$ & $\begin{array}{c}\text { Desa } \\
\text { (Village) } \\
\text { Kalijaya }\end{array}$ & $\begin{array}{c}\text { Desa } \\
\text { (Village) } \\
\text { Kertaharja }\end{array}$ \\
\cline { 3 - 8 } & & PU & PS & PU & PS & PU & PS \\
\hline 1 & PNS/Pensiunan (Government pensioner) & 0 & 0 & 2 & 0 & 0 & 0 \\
2 & Dagang (Trader) & 3 & 1 & 0 & 3 & 3 & 1 \\
3 & Supir (Driver) & 1 & 0 & 0 & 0 & 0 & 0 \\
4 & Aparat Desa (Village officer) & 1 & 0 & 1 & 0 & 1 & 0 \\
5 & Peternak (Breeder) & 1 & 2 & 0 & 0 & 0 & 0 \\
6 & Montir/bengkel (Mechanic) & 1 & 0 & 2 & 0 & 0 & 0 \\
7 & Pekerja kontrak (Contract worker) & 1 & 0 & 1 & 0 & 0 & 0 \\
8 & Petani (Farmer) & 12 & 8 & 13 & 7 & 15 & 5 \\
9 & Penggilingan padi (Paddy grinder) & 0 & 0 & 1 & 0 & 0 & 0 \\
10 & Buruh (Labour) & 0 & 0 & 0 & 2 & 1 & 8 \\
11 & Wiraswasta (Businessmen) & 0 & 1 & 0 & 0 & 0 & 0 \\
12 & Guru Agama (Religion teacher) & 0 & 0 & 0 & 0 & 0 & 1 \\
\hline
\end{tabular}

Note : PU= Pekerjaan utama (Main job), PS = Pekerjaan sampingan (Side job)

SumberSources: diolah dari data primer 2010 (Processed from the primary data, 2010) 
menekuni pekerjaan-pekerjaan yang sudah terbiasa dilakukan yaitu bertani dan jarang yang mencoba usaha lain. Hal ini disebabkan sebagian besar petani di Desa Kertaharja telah memiliki pekerjaan sebagai pengrajin gula kelapa.

\section{Jumlah tanggungan keluarga responden}

Jumlah tanggungan keluarga merupakan indikator untuk melihat banyaknya anggota keluarga yang berada dalam lingkungan keluarga dan menjadi tanggungan responden (Pujianto, 2008). Banyak tidaknya jumlah tanggungan keluarga terutama tanggungan keluarga yang masih balita, akan memperlihatkan kemungkinan-kemungkinan keterlibatan anggota keluarga terutama istri dalam pengelolaan hutan rakyat maupun kegiatan non-domestik lainnya. Seperti pendapat El- iana \& Ratina (2006) yang menyatakan bahwa dengan tidak ada tanggungan anak balita akan memudahkan istri untuk keluar dari sektor domestik (rumah tangga) untuk terlibat pada sektor produktif yaitu mencari nafkah.

Rata-rata responden termasuk pada umur produktif, yang secara umum masih mempunyai banyak tanggungan keluarga. Hasil analisa data menunjukkan bahwa di setiap lokasi penelitian, pada usia produktif ini tanggungan keluarga berkisar antara 3-4 orang yang meliputi istri, anak, dan sanak saudara yang masih dibiayai oleh kepala keluarga. Jumlah tanggungan keluarga terbanyak ada enam orang yang dimiliki oleh satu responden di Desa Ciomas dan dua responden di Desa Kertaharja sebagaimana diperlihatkan oleh

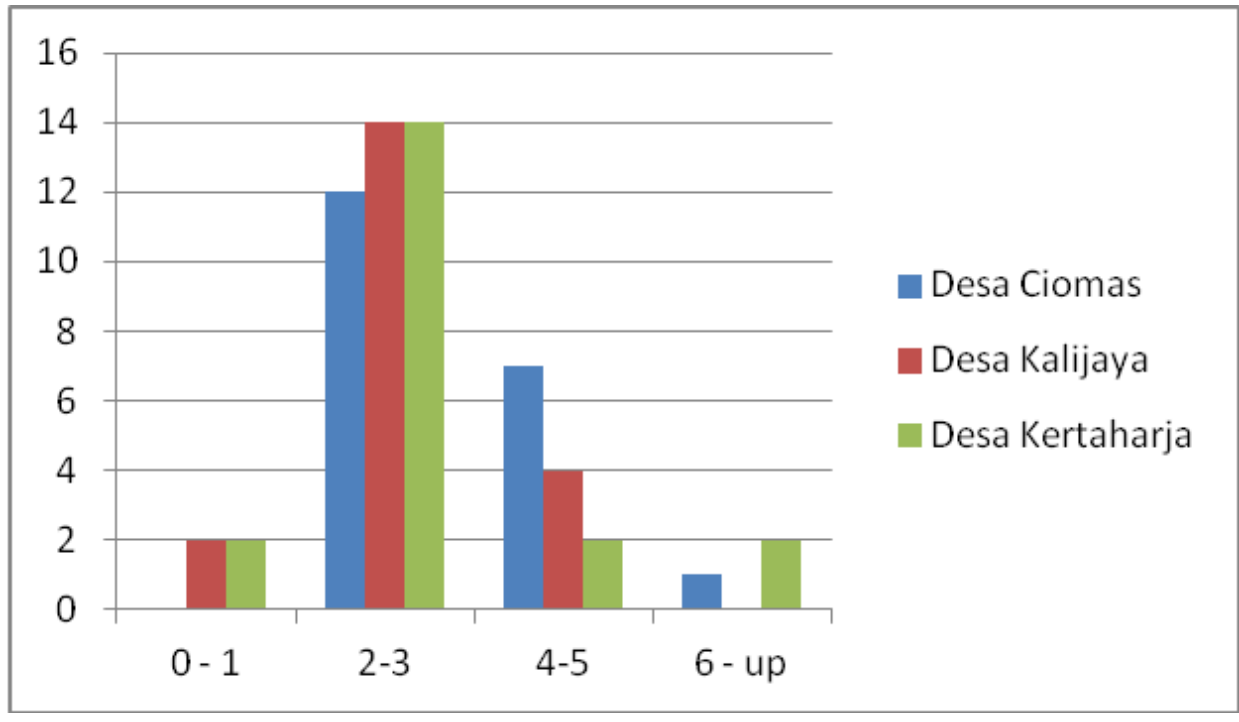

Gambar(Figure) 3. Jumlah tanggungan keluarga responden di lokasi penelitian (The number of dependent family of respondent in research location)

\section{Gambar3.}

Tenaga kerja yang terlibat pada pengelolaan hutan rakyat utamanya adalah anggota keluarga, sehingga sering disebut sebagai manajemen keluarga. Oleh karena itu banyaknya tanggungan keluarga petani juga bisa dipandang sebagai aset yang berpotensi memperlancar kegiatan usaha hutan rakyat. Semakin besar anggota keluarga cenderung semakin mudah masalah pengelolaan hutan rakyat bisa dipecahkan.

\section{Lama tinggal di desa}

Petani yang menjadi responden pada umum- nya sudah tinggal di desa lebih dari 35 tahun, walaupun awalnya sebagian bukan merupakan penduduk asli yang lahir di desa. Namun karena sudah lama menetap di desa sehingga sudah merasa menjadi penduduk asli desa. Untuk melihat status responden di desa dapat dilihat pada Tabel 4. Penduduk yang paling lama tinggal di desa yaitu responden di Desa Ciomas dengan rata-rata tinggal di desa selama 49 tahun, sedangkan yang paling sebentar tinggal di desa adalah petani yang berada di Desa Kertaharja rata-rata selama 35 tahun. Sementara itu petani responden di Desa Kalijaya rata-rata telah tinggal di desa selama 40 
Tabel (Table) 4. Status Responden di desa (Status of respondent in the village)

\begin{tabular}{|c|c|c|c|c|c|c|c|c|c|}
\hline \multirow{3}{*}{$\begin{array}{l}\text { Kelompok } \\
\text { umur (Tahun) } \\
\text { (Age group } \\
\text { (Year) }\end{array}$} & \multicolumn{3}{|c|}{ Desa (Village) Ciomas } & \multicolumn{3}{|c|}{ Desa (Village) Kalijaya } & \multicolumn{3}{|c|}{ Desa (Village) Kertaharja } \\
\hline & \multirow{2}{*}{$\begin{array}{l}\text { Lama di } \\
\text { Desa (Tahun) } \\
\text { (Resident } \\
\text { Status } \\
\text { (Years) }\end{array}$} & \multicolumn{2}{|c|}{$\begin{array}{c}\text { Status } \\
\text { Penduduk } \\
\text { (Resident } \\
\text { status) }\end{array}$} & \multirow[t]{2}{*}{$\begin{array}{l}\text { Lama di } \\
\text { Desa(Tahun) } \\
\text { (Resident } \\
\text { status) } \\
\text { (Years) }\end{array}$} & \multicolumn{2}{|c|}{$\begin{array}{l}\text { Status } \\
\text { Penduduk } \\
\text { (Resident } \\
\text { status) }\end{array}$} & \multirow[t]{2}{*}{$\begin{array}{l}\text { Lama di } \\
\text { Desa(Tahun) } \\
\text { (Resident } \\
\text { status(Years) }\end{array}$} & \multicolumn{2}{|c|}{$\begin{array}{c}\text { Status } \\
\text { Penduduk } \\
\text { (Resident } \\
\text { status) }\end{array}$} \\
\hline & & As & $\mathrm{Pd}$ & & As & $\mathrm{Pd}$ & & As & $\mathrm{Pd}$ \\
\hline $20-29$ & 0 & 0 & 0 & 0 & 0 & 0 & 28 & 2 & 0 \\
\hline $30-39$ & 32 & 2 & 0 & 35 & 3 & 0 & 26 & 2 & 1 \\
\hline $40-49$ & 43 & 6 & 0 & 39 & 8 & 2 & 38 & 4 & 4 \\
\hline $50-59$ & 46 & 8 & 1 & 40 & 5 & 1 & 42 & 2 & 2 \\
\hline $60-69$ & 61 & 2 & 0 & 60 & 1 & 0 & 31 & 0 & 3 \\
\hline 70 up & 70 & 1 & 0 & 0 & (1) & 0 & & 0 & 0 \\
\hline Rata-rata & 49 & & & 40 & & & & & \\
\hline
\end{tabular}

Keterangan : As $=$ asli (indigeneous), $\mathrm{Pd}=$ pendatang (migrant)

Sumber; Diolah dari data primer 2010 (Sources: processed from the primary data, 2010)

tahun.

Penduduk pendatang terbanyak berada di Desa Kertaharja karena desa ini pada awalnya merupakan areal perkebunan kelapa yang pengembangannya memerlukan banyak tenaga kerja sehingga pengelola perkebunan mendatangkan tenaga kerja dari luar desa yang umumnya berasal dari Kabupaten Kebumen. Tenaga kerja ini diperlukan untuk memanen nira kelapa dan mengolahnya menjadi gula merah. Lama-kelamaan tenaga kerja tersebut akhirnya menetap di Desa Kertaharja walaupun perkebunan sudah tidak berkembang lagi. Desa Kertaharja merupakan desa yang berada di wilayah pembangunan Ciamis bagian selatan yaitu wilayah dataran rendah (pantai), penduduknya lebih terbuka, lebih dinamis, dan desa ini berbatasan dengan wilayah Propinsi Jawa Tengah sehingga memudahkan penduduk untuk melakukan migrasi antar desa. Desa yang paling sedikit pendatangnya adalah Desa Ciomas yakni hanya 1 orang. Desa ini berada di wilayah pembangunan Ciamis bagian utara yaitu wilayah pegunungan sehingga penduduknya cenderung sebagai petani yang sifatnya lebih statis.

Umur pendatang rata-rata lebih dari 30 tahun, tergolong pada umur yang produktif dan sudah dewasa. Alasan utama petani mau melakukan migrasi diantaranya mengikuti orang tua, mengikuti suami, mengikuti saudara dan mencari pekerjaan yang lebih baik.

\section{Tingkat Pendapatan dan Pengeluaran Responden}

Tingkat pendapatan sangat dipengaruhi oleh usaha yang dilakukan oleh petani. Berdasarkan data pada Tabel 3 diketahui bahwa usaha yang dilakukan oleh responden berasal dari beberapa sumber. Pendapatan responden merupakan hasil dari seluruh usaha yang dilakukan oleh responden selama satu tahun.

Pendapatan yang dihasilkan oleh petani menggambarkan tingkat kemampuan petani untuk berdaya beli sehingga dapat memenuhi kebutuhan hidupnya. Seperti dikemukakan oleh Khususiyah et al. (2010) bahwa pendapatan rumah tangga petani dapat mencerminkan keadaan ekonomi rumah tangganya. Tinggi rendahnya tingkat pendapatan rumah tangga dapat digunakan sebagai salah satu indikator tinggi rendahnya tingkat kesejahteraan suatu rumah tangga.

Sumber pendapatan responden dikelompokkan menjadi 6 yaitu pendapatan yang berasal dari hutan rakyat, jasa, hasil dari keluarga (usaha istri/suami, kiriman dari anak, pemberian orang tua), pendapatan dari sawah, hasil dari hewan ternak dan pendapatan dari kolam ikan.

Dari hasil perhitungan diketahui bahwa sumber pendapatan yang paling besar dihasilkan dari hutan rakyat dan jasa. Hasil hutan rakyat yang besar ini sangat wajar karena umumnya responden mengaku pekerjaan utamanya sebagai petani sehingga pendapatan yang terbesar adalah pendapatan yang berbasis lahan hutan rakyat, berupa hasil kayu dan hasil hutan bukan kayu seperti tanaman perkebunan dan tanaman semusim. Selain itu berdasarkan data Tabel 8 diketahui bahwa lahan untuk usaha hutan rakyat menempati urutan paling luas dibandingkan lahan untuk sawah. Hal ini berhubungan dengan 
kondisi biofisik yang hanya memungkinkan penggunaanya untuk hutan rakyat dibandingkan sawah. Kondisi ini sangat mendukung bagi usaha hutan rakyat. Seluruh responden menganggap bahwa pekerjaan sebagai petani merupakan pekerjaan yang diminati oleh seluruh responden baik

Tabel (Table) 5. Pendapatan rata-rata responden (Average income of respondents)

\begin{tabular}{|c|c|c|c|c|c|c|c|}
\hline \multirow[b]{2}{*}{$\begin{array}{l}\text { No } \\
\text { (no) }\end{array}$} & \multirow[b]{2}{*}{$\begin{array}{l}\text { Sumber Pendapatan } \\
\text { (Sources of income) }\end{array}$} & \multicolumn{2}{|c|}{ Desa (village) Ciomas } & \multicolumn{2}{|c|}{$\begin{array}{l}\text { Desa (village) } \\
\text { Kalijaya }\end{array}$} & \multicolumn{2}{|c|}{$\begin{array}{c}\text { Desa (village) } \\
\text { Kertaharja }\end{array}$} \\
\hline & & $\begin{array}{c}\text { Rata-rata } \\
\text { pendapatan } \\
\text { (Rp/thn) } \\
\text { (Average } \\
\text { income } \\
\text { (Rp/year)) }\end{array}$ & $\%$ & $\begin{array}{c}\text { Rata-rata } \\
\text { pendapatan } \\
\text { (Rp/thn) } \\
\text { (Average } \\
\text { income } \\
\text { (Rp/year)) }\end{array}$ & $\%$ & $\begin{array}{c}\text { Rata-rata } \\
\text { pendapatan } \\
\text { (Rp/thn) } \\
\text { (Average } \\
\text { income } \\
\text { (Rp/year)) }\end{array}$ & $\%$ \\
\hline 1 & $\begin{array}{l}\text { Hutan Rakyat (private } \\
\text { forest) }\end{array}$ & 7.493 .232 & 35,72 & 11.180 .002 & 35,08 & 8.956 .809 & 42,81 \\
\hline 2 & Jasa(service) & 9.334 .000 & 44,49 & 10.160 .450 & 31,88 & 7.414 .000 & 35,43 \\
\hline 3 & Keluarga(family) & 1.178 .000 & 5,60 & 6.430 .100 & 20,17 & 2.599 .500 & 12,42 \\
\hline 4 & Sawah(paddy field) & 783.750 & 3,74 & 2.316 .500 & 7,27 & 1.333 .300 & 6,37 \\
\hline 5 & Hewan ternak(cattle) & 1.848 .000 & 8,81 & 215.000 & 0,67 & 601.500 & 2,87 \\
\hline 6 & Kolam Ikan(fish pool) & 343.600 & 1,64 & 1.571 .475 & 4,93 & 18.750 & 0,09 \\
\hline & Total(total) & 20.980 .582 & 100 & 31.873 .527 & 100 & 20.923 .859 & 100 \\
\hline
\end{tabular}

Sumber (Resources): Achmad dan Ris, (2014)

itu sebagai pekerjaan utama ataupun sampingan.

Berdasarkan data dari Tabel 5 diketahui bahwa pendapatan paling besar berasal dari hutan rakyat terdapat di Desa Kalijaya (Rp 11.180.002/ tahun) dan Kertaharja (Rp 8.956.809/tahun). Pendapatan paling besar berasal dari jasa terjadi di Desa Ciomas (Rp 9.334.000/tahun). Perbedaan pendapatan ini disebabkan terutama oleh perbedaan rata-rata luas kepemilikan lahan petani, juga karena adanya perbedaan harga kayu yang berkaitan dengan aksesibilitas. Topografi Desa Kalijaya dan Desa Kertaharja relatif lebih landai dibandingkan dengan Desa Ciomas sehingga kayunya dihargai relatif lebih mahal karena biaya pemanenan pohon lebih murah. Selain itu industri pengolahan kayu lebih berminat membeli kayu dari daerah selatan karena dari segi mutu juga lebih tinggi yakni relatif lebih lurus, mulus dan kurang mengandung mata kayu. Postur pohon sengon menjadi lebih lurus dan minim percabangan karena anakan sengon berusaha mencapai tajuk tanaman kelapa untuk mendapatkan cahaya sehingga pertumbuhan tingginya lebih cepat. Sumber pendapatan yang lain, memberikan kontribusi namun kecil dan tidak rutin. Oleh karena itu biasanya sumber-sumber tersebut ditekuni petani hanya untuk memenuhi kebutuhan sendiri dan sangat jarang dikomersialkan, seperti usaha padi sawah, kolam ikan, ternak dan usaha dari keluarga.

Pendapatan petani mencerminkan daya beli petani yang juga dapat diketahui melalui pendekatan pola konsumsinya. Tabel 6 memperlihatkan tingkat pengeluaran responden petani bersama keluarganya. Dari hasil perhitungan diketahui bahwa pengeluaran untuk pangan yang paling dominan untuk seluruh lokasi penelitian, yaitu berkisar antara 50-60\%. Pengeluaran kedua untuk pendidikan yaitu berkisar antara $12-24 \%$. Petani sudah memperhatikan kondisi pendidikan anakanaknya, sehingga pengeluaran pendidikan lebih utama dibandingkan dengan pengeluaran untuk sandang, papan, kesehatan dan lain-lain. Bagi bangsa yang ingin maju dan berhasil dalam pembangunan, pendidikan merupakan kebutuhan yang sama seperti kebutuhan seharihari seperti perumahan, sandang, dan pangan (Tanjung, 2012). Pengeluaran untuk sandang tidak menjadi perhatian bagi sebagian responden karena adakalanya sandang sering diberi oleh 
Tabel(Table) 6. Rata-rata pengeluran responden petani per tahun (The average of budged spending by respondent per annum)

\begin{tabular}{|c|c|c|c|c|c|c|}
\hline \multirow[b]{2}{*}{$\begin{array}{l}\text { Jenis Pengeluaran } \\
\text { (Kind of spending) }\end{array}$} & \multicolumn{2}{|c|}{ Desa (Village) Ciomas } & \multicolumn{2}{|c|}{ Desa (Village) Kalijaya } & \multicolumn{2}{|c|}{ Desa (Village) Kertaharja } \\
\hline & $\begin{array}{c}\text { Rata-rata } \\
\text { pengeluaran } \\
\text { (Rp/thn) } \\
\text { (Average } \\
\text { expenditure } \\
\text { (Rp/year) }\end{array}$ & $(\%)$ & $\begin{array}{c}\text { Rata-rata } \\
\text { pengeluaran } \\
\text { (Rp/thn) } \\
\text { (Average } \\
\text { expenditure } \\
\text { (Rp/year }\end{array}$ & $(\%)$ & $\begin{array}{c}\text { Rata-rata } \\
\text { pengeluaran } \\
\text { (Rp/thn) } \\
\text { (Average } \\
\text { expenditure } \\
\text { (Rp/year }\end{array}$ & $(\%)$ \\
\hline Pangan (Food) & 7.713 .255 & 55 & 7.997 .456 & 50 & 8.855 .275 & 60 \\
\hline Pendidikan (Education) & 3.399 .400 & 24,2 & 3.236 .000 & 20 & 2.421 .175 & 16 \\
\hline Sandang (Clothing) & 1.017 .500 & 7,3 & 1.046 .500 & 7 & 1.091 .200 & 7 \\
\hline Papan (House) & 748.275 & 5,3 & 785.950 & 5 & 444.875 & 3 \\
\hline Kesehatan (Health) & 284.000 & 2,1 & 743.250 & 5 & 395.850 & 3 \\
\hline Lain-lain (Others) & 863.000 & 6,1 & 2.146 .250 & 13 & 1.658 .500 & 11 \\
\hline Total (Total) & 14.125 .430 & 100 & 15.955 .406 & 100 & 14.866 .875 & 100 \\
\hline
\end{tabular}

saudara ataupun anak.

Dari hasil pengurangan antara pendapatan dan pengeluaran responden akan diketahui apakah terdapat surplus atau defisit pendapatan. Jika pendapatannya positif berarti terdapat surplus pendapatan sehingga menunjukkan bawah petani sudah mampu memenuhi seluruh kebutuhannya dengan hasil pendapatan dari usaha yang dilakukannya. Untuk melihat tingkat surplus pendapatan petani dapat dilihat pada Tabel 7.

Berdasarkan hasil pengurangan pendapatan dan pengeluaran diketahui bahwa di seluruh lokasi penelitian, petaninya mampu memenuhi kebutuhan atau surplus (pendapatannya positif).

Berdasarkan rata-rata total pendapatan yang dihasilkan oleh responden, selanjutnya dianalisis mengenai distribusi pendapatan responden sehingga diketahui tingkat pemerataan pendapatan petani hutan rakyat di seluruh lokasi penelitian. Dari hasil perhitungan menunjukkan bahwa nilai koefisien gini (KG) bagi petani di Ciomas adalah 0,56 dan termasuk dalam kategori ketimpangan tinggi karena $\mathrm{KG}>0,5$. Hal ini menunjukkan bahwa pendapatan petani hutan rakyat di Ciomas tidak merata yaitu ada perbedaan pendapatan yang besar antara petani hutan rakyat yang kaya dan petani hutan rakyat yang miskin. Distribusi pendapatan yang tidak merata ini dapat disebabkan oleh beberapa faktor diantarnya kepemilikan lahan yang tidak merata sehingga terdapat perbedaan hasil dari usaha yang berbasis lahan. Kontribusi pendapatan responden tertinggi di Desa Ciomas adalah dari sektor jasa yaitu sebesar $44,49 \%$ bersumber dari usaha dagang, bengkel dan supir, namun diduga tidak semua penduduk mempunyai peluang untuk bekerja di sektor tersebut. Selain itu tingkat pendidikan yang rata-rata masih rendah akan berdampak terhadap penerimaan informasi dan

Tabel (Table) 7. Besaran surplus pendapatan petani (The amount of income surplus offarmers).

\begin{tabular}{ccccc}
\hline $\begin{array}{c}\text { No } \\
\text { (No) }\end{array}$ & $\begin{array}{c}\text { Desa } \\
\text { (Village) }\end{array}$ & $\begin{array}{c}\text { Total Rata-rata } \\
\text { pendapatan(Total of } \\
\text { average income) } \\
\text { (IDR/year) }\end{array}$ & $\begin{array}{c}\text { Total Rata-rata } \\
\text { pengeluaran(Total of } \\
\text { average spending) } \\
\text { (IDR/year) }\end{array}$ & $\begin{array}{c}\text { Surplus pendapatan } \\
\text { (Total of average } \\
\text { saving)(IDR/year) }\end{array}$ \\
\hline 1 & Ciomas & 20.980 .582 & 14.125 .430 & 6.855 .152 \\
2 & Kalijaya & 31.873 .527 & 15.955 .406 & 15.918 .121 \\
3 & Kertaharja & 24.536 .559 & 14.866 .875 & 9.669 .684 \\
\hline
\end{tabular}

Sumber: diolah dari data primer 2010 (Resources: analized from the primary data, 2010) 
peluang berusaha yang sempit, seperti disampaikan oleh Sudaryanto et al. (1981) bahwa tingkat pendidikan juga berpengaruh terhadap tingkat upah, bagi kelompok rumah tangga petani yang kurang pendidikan, lebih terbatas kesempatannya untuk bekerja di sektor-sektor yang memberikan upah lebih tinggi.

Nilai KG di Desa Kalijaya adalah 0,47 dan Desa Kertaharja sebesar 0.46836 yang termasuk pada kriteria KG 0,4-0,5 yaitu tingkat ketimpangan sedang dimana distribusi pendapatan responden petani hutan rakyat hampir mendekati merata.

Selanjutnya dilakukan analisis garis kemiskinan responden berdasarkan Sajogyo (1988) dalam Simanjuntak (2007) yang menyatakan bahwa garis kemiskinan adalah besarnya pendapatan perkapita yang setara dengan nilai tukar $320 \mathrm{~kg}$ beras/kapita/tahun. Jika harga beras di Desa Ciomas adalah Rp 6.000 berarti tingkat pendapatan $\mathrm{Rp}$ 1.920.000/tahun termasuk miskin. Jika dibandingkan dengan hasil perhitungan pendapatan di Desa Ciomas rata-rata sebesar Rp 20.980.582/tahun, berarti bahwa petani di Desa Ciomas sudah berada jauh di atas garis kemiskinan.

Harga beras di Desa Kalijaya adalah Rp $5.000 / \mathrm{kg}$ maka jumlah pendapatan yang termasuk pada selang garis kemiskinan adalah
Rp 1.600.000/thn. Apabila dibandingkan dengan tingkat pendapatan rata-rata responden sebesar Rp 31.873.527/tahun, maka petani di Desa Kalijaya berada jauh di atas garis kemiskinan menurut kriteria Sajogyo (1988).

Harga Beras di Desa Kertaharja Rp 5.000 maka tingkat pendapatan yang termasuk pada garis kemiskinan sebesar Rp 1.600.000/tahun. Selanjutnya jika dibandingkan dengan tingkat pendapatan rata-rata petani di Desa Kertaharja berjumlah Rp 24.536.559/tahun, maka responden di Desa Kertaharja ini sudah berada jauh di atas garis kemiskinan.

\section{Penguasaan lahan dan pola tanam hutan rakyat}

Kesejahteraan petani dapat ditingkatkan salah satunya melalui penguasaan lahan oleh petani sebagaimana dikemukakan oleh Susilowati dan Maulana (2012). Rata-rata luas penguasaan lahan di ketiga lokasi penelitian disajikan dalam Tabel 8 berikut ini. Sebagian besar lahan yang diusahakan adalah lahan hutan rakyat yang ditanami campuran antara tanaman kayu dengan jenis lainnya seperti sengon, mahoni, afrika, manglid, kapulaga, pisang, kelapa dan singkong, dengan rata-rata penguasaan lahan setiap petaninya adalah 0,7737 ha (Desa Ciomas), 2,078 ha (Desa Kalijaya) dan 0,7271 ha (Desa

Tabel (Table) 8. Rataan pengusaan lahan responden di lokasi penelitian (The average of land managed by respondent in research location)

\begin{tabular}{|c|c|c|c|c|c|c|}
\hline \multirow{3}{*}{$\begin{array}{l}\text { Jenis Lahan } \\
\text { (Kind of Land) }\end{array}$} & \multicolumn{6}{|c|}{ Lokasi Penelitian(Research Sites) } \\
\hline & \multicolumn{2}{|c|}{$\begin{array}{l}\text { Desa Ciomas } \\
\text { (Ciomas Village) }\end{array}$} & \multicolumn{2}{|c|}{$\begin{array}{c}\text { Desa Kalijaya } \\
\text { (Kalijaya Village) }\end{array}$} & \multicolumn{2}{|c|}{$\begin{array}{c}\text { Desa Kertaharja } \\
\text { (Kertaharja Village) }\end{array}$} \\
\hline & $\begin{array}{l}\text { Luas } \\
\text { (ha) }\end{array}$ & $\%$ & $\begin{array}{l}\text { Luas } \\
\text { (ha) }\end{array}$ & $\%$ & $\begin{array}{l}\text { Luas } \\
\text { (ha) }\end{array}$ & $\%$ \\
\hline Hutan rakyat (Privateforest) & 0,7737 & 82,07 & 2,078 & 89,33 & 0,7271 & 76,02 \\
\hline Sawah(Paddy field) & 0,0746 & 7,91 & 0,162 & 6,95 & 0,1190 & 12,44 \\
\hline $\begin{array}{l}\text { Pekarangan dan Rumah } \\
\text { (Garden andhouse) }\end{array}$ & 0,0539 & 5,73 & 0,073 & 3,12 & 0,1091 & 11,41 \\
\hline Kolam Ikan (Fish pool) & 0,0405 & 4,29 & 0,014 & 0,61 & 0,0012 & 0,13 \\
\hline Total (total) & 0,9427 & 100 & 2,327 & 100 & 0,9564 & 100 \\
\hline
\end{tabular}

Sumber:Resources: Diolah dari data primer 2010 ( Analized from the primary data, 2010)

Kertaharja).

Pola tanam hutan rakyat yang dilakukan oleh responden di setiap wilayah pengembangan Kabupaten Ciamis seperti dilaporkan oleh Achmad
\& Ris (2014) berikut ini:

1. Wilayah Pembangunan Ciamis Utara, teridentifikasi tiga pola agroforestri hutan rakyat, seperti tercantum pada Tabel 9 berikut 
Tabel (Table) 9. Hutan rakyat pola agroforestri di Desa Ciomas (Ciamis Utara) (Agroforestry pattern of private forest in Ciomas Village (North Ciamis))

\begin{tabular}{|c|c|c|c|c|c|c|}
\hline No. & $\begin{array}{l}\text { Pola } \\
\text { (Pattern) }\end{array}$ & $\begin{array}{l}\text { Tanaman } \\
\text { kayu } \\
\text { (Timber } \\
\text { plants) }\end{array}$ & $\begin{array}{l}\text { Tanaman } \\
\text { perkebunan } \\
\text { (Plantation } \\
\text { crops) }\end{array}$ & $\begin{array}{l}\text { Tanaman } \\
\text { buah } \\
\text { (Fruitcrops) }\end{array}$ & $\begin{array}{l}\text { Tanaman obat } \\
\text { (Medicinal } \\
\text { plants) }\end{array}$ & $\begin{array}{c}\text { Tanaman } \\
\text { pangan } \\
\text { (Food } \\
\text { crops) }\end{array}$ \\
\hline 1 & $\begin{array}{l}\text { Tanaman penghasil } \\
\text { kayu }+ \text { tanaman } \\
\text { perkebunan }+ \text { tanaman } \\
\text { penghasil buah }+ \text { tanaman } \\
\text { obat }\end{array}$ & $\begin{array}{l}\text { sengon, } \\
\text { mahoni, } \\
\text { afrika, } \\
\text { manglid }\end{array}$ & Kelapa & Pisang & Kapulaga & - \\
\hline 2 & $\begin{array}{l}\text { Tanaman penghasil } \\
\text { kayu }+ \text { tanaman } \\
\text { perkebunan }+ \text { tanaman } \\
\text { penghasil buah }+ \text { tanaman } \\
\text { obat }+ \text { tanaman pangan }\end{array}$ & $\begin{array}{l}\text { sengon, } \\
\text { mahoni, } \\
\text { afrika }\end{array}$ & Kelapa & Pisang & Kapulaga & Singkong \\
\hline 3 & $\begin{array}{l}\text { Tanaman penghasil kayu } \\
+ \text { tanaman penghasil buah } \\
+ \text { tanaman obat }\end{array}$ & $\begin{array}{l}\text { sengon, } \\
\text { mahoni }\end{array}$ & - & Pisang & Kapulaga & - \\
\hline
\end{tabular}

Sumber (Sources): Achmad and Ris (2014)

ini:

Tanaman pohon yang menjadi ciri khas hutan rakyat di wilayah ini adalah sengon, mahoni dan manglid yang dipadukan dengan tanaman pangan seperti singkong, tanaman buah seperti pisang dan tanaman bawah berupa tanaman obat yaitu kapulaga. Manglid merupakan jenis pohon yang diharapkan dapat mengganti posisi sengon yang terserang karat tumor.

2. Wilayah Pembangunan Ciamis Tengah, teridentifikasi jenis tanaman penyusun hutan rakyatnya lebih beragam. Di wilayah ini dijumpai pohon jati walaupun jumlahnya tidak banyak. Tanaman Penyusun hutan

Tabel (Table) 10. Hutan rakyat pola agroforestri di Desa Kalijaya (Ciamis Tengah) (Agroforestry pattern of privateforest in Kalijaya Village (Central Ciamis))

\begin{tabular}{|c|c|c|c|c|c|}
\hline $\begin{array}{l}\text { No. } \\
\text { (No) }\end{array}$ & $\begin{array}{c}\text { Pola } \\
\text { (Pattern) }\end{array}$ & $\begin{array}{l}\text { Tanaman kayu } \\
\text { (Timber plants) }\end{array}$ & $\begin{array}{l}\text { Tanaman } \\
\text { perkebunan } \\
\text { (Plantation } \\
\text { crops) }\end{array}$ & $\begin{array}{l}\text { Tanaman } \\
\text { buah (Fruit } \\
\text { crops) }\end{array}$ & $\begin{array}{l}\text { Tanaman } \\
\text { obat } \\
\text { (Medicinal } \\
\text { plants) }\end{array}$ \\
\hline 1 & $\begin{array}{l}\text { Tanaman penghasil kayu }+ \\
\text { tanaman perkebunan }+ \text { tanaman } \\
\text { penghasil buah }+ \text { tanaman obat }\end{array}$ & $\begin{array}{l}\text { Sengon, } \\
\text { mahoni, tisuk }\end{array}$ & $\begin{array}{l}\text { Kelapa, } \\
\text { coklat }\end{array}$ & $\begin{array}{l}\text { Pisang, } \\
\text { mangga }\end{array}$ & Kapulaga \\
\hline 2 & $\begin{array}{l}\text { Tanaman penghasil kayu }+ \\
\text { tanaman perkebunan }+ \text { tanaman } \\
\text { penghasil buah }\end{array}$ & $\begin{array}{l}\text { Sengon, } \\
\text { mahoni }\end{array}$ & $\begin{array}{l}\text { Kelapa, } \\
\text { coklat }\end{array}$ & $\begin{array}{l}\text { Pisang, } \\
\text { mangga }\end{array}$ & - \\
\hline 3 & $\begin{array}{l}\text { Tanaman penghasil kayu }+ \\
\text { tanaman penghasil buah }\end{array}$ & $\begin{array}{l}\text { Sengon, } \\
\text { mahoni }\end{array}$ & - & $\begin{array}{l}\text { Pisang, } \\
\text { mangga }\end{array}$ & - \\
\hline 4 & $\begin{array}{l}\text { Tanaman penghasil kayu }+ \\
\text { tanaman perkebunan }+ \text { tanaman } \\
\text { obat }\end{array}$ & $\begin{array}{l}\text { Sengon, } \\
\text { mahoni }\end{array}$ & $\begin{array}{l}\text { Kelapa } \\
\text { coklat }\end{array}$ & - & Kapulaga \\
\hline 5 & $\begin{array}{l}\text { Tanaman penghasil kayu }+ \\
\text { tanaman obat }\end{array}$ & $\begin{array}{l}\text { Sengon, } \\
\text { mahoni }\end{array}$ & - & - & Kapulaga \\
\hline
\end{tabular}

Sumber (sources) : Achmad dan Ris, (2014) 
rakyatnya seperti disajikan oleh Tabel 10.

Pohon sengon, mahoni serta tisuk merupakan jenis dominan yang banyak terdapat di hutan rakyat di Desa Kalijaya. Tanaman kebun yang banyak dijumpai yaitu kelapa dan coklat, tanaman buah didominasi pisang dan mangga, sedangkan tanaman obat yaitu kapulaga.

3. Tanaman bawah seperti tanaman obat di wilayah Ciamis selatan belum dieksplorasi secara maksimal, kalaupun ada tanaman bawah biasanya hanya beberapa rumpun saja. Adapun pola tanam hutan rakyat di wilayah

Tabel(Table) 11. Hutan rakyat pola agroforestry Di Desa Kertaharja (Ciamis Selatan) (Agroforestry pattern of private forest in Kertaharja Village (South Ciamis)

\begin{tabular}{|c|c|c|c|c|c|c|}
\hline No. & $\begin{array}{l}\text { Pola } \\
\text { (Pattern) }\end{array}$ & $\begin{array}{l}\text { Tanaman } \\
\text { kayu } \\
\text { (Timberplants) }\end{array}$ & $\begin{array}{l}\text { Tanaman } \\
\text { perkebun } \\
\text { an(Planta } \\
\quad \text { tion } \\
\text { crops })\end{array}$ & $\begin{array}{l}\text { Tanaman } \\
\text { buah } \\
\text { (Fruit } \\
\text { crops) }\end{array}$ & $\begin{array}{l}\text { Tanaman } \\
\text { obat } \\
\text { (Medicin } \\
\text { alplants) }\end{array}$ & $\begin{array}{l}\text { Tanaman } \\
\text { pangan } \\
\text { (Food } \\
\text { crops) }\end{array}$ \\
\hline 1 & $\begin{array}{l}\text { Tanaman penghasil kayu }+ \text { tanaman } \\
\text { perkebunan }+ \text { tanaman penghasil } \\
\text { buah }+ \text { tanaman pangan }\end{array}$ & $\begin{array}{l}\text { sengon, } \\
\text { mahoni }\end{array}$ & kelapa & pisang & - & singkong \\
\hline 2 & $\begin{array}{l}\text { Tanaman penghasil kayu }+ \text { tanaman } \\
\text { perkebunan }+ \text { tanaman penghasil } \\
\text { buah }\end{array}$ & $\begin{array}{l}\text { sengon, } \\
\text { mahoni, jati, } \\
\text { ganitri, huru }\end{array}$ & $\begin{array}{l}\text { kelapa, } \\
\text { cengkeh, } \\
\text { kopi }\end{array}$ & $\begin{array}{l}\text { pisang, } \\
\text { petai }\end{array}$ & - & - \\
\hline 3 & $\begin{array}{l}\text { Tanaman penghasil kayu }+ \text { tanaman } \\
\text { perkebunan }+ \text { tanaman penghasil } \\
\text { buah }+ \text { tanaman obat }\end{array}$ & $\begin{array}{l}\text { sengon, } \\
\text { mahoni, jati, } \\
\text { huru, ganitri }\end{array}$ & kelapa & pisang & kapulaga & - \\
\hline 4 & $\begin{array}{l}\text { Tanaman penghasil kayu }+ \text { tanaman } \\
\text { penghasil buah }\end{array}$ & $\begin{array}{l}\text { sengon, } \\
\text { mahoni, }\end{array}$ & - & pisang & - & - \\
\hline 5 & $\begin{array}{l}\text { Tanaman penghasil kayu }+ \text { tanaman } \\
\text { perkebunan }+ \text { tanaman penghasil } \\
\text { buah }+ \text { tanaman obat }+ \text { tanaman } \\
\text { pangan }\end{array}$ & $\begin{array}{l}\text { akasia } \\
\text { sengon, } \\
\text { mahoni, jati, } \\
\text { akasia }\end{array}$ & cengkeh & petai & $\begin{array}{l}\text { kapulaga, } \\
\text { merica }\end{array}$ & singkong \\
\hline
\end{tabular}

Sumber (Sources) : Achmad and Ris (2014)

ini diperlihatkan oleh Tabel 11.

Jenis dan jumlah pohon yang dikembangkan di wilayah Selatan sudah mulai banyak seperti: jati, huru, ganitri dan akasia. Namun demikian, di wilayah ini sengon dan mahoni masih merupakan tanaman primadona. Tanaman lainnya yang menjadi ciri dari wilayah selatan adalah melimpahnya tanaman kelapa, karena responden dari wilayah ini mayoritas merupakan bekas penggarap perkebunan kelapa. Kelapa yang ada di Desa Kertaharja dimanfaatkan secara komersial yaitu untuk pembuatan gula kelapa. Hasil dari penjualan gula kelapa cukup besar dan dapat memenuhi kebutuhan sehari-hari petani serta memberikan kontribusi yang besar terhadap total pendapatan responden dari hutan rakyat. Berbeda dengan Desa Ciomas dan Desa Kalijaya, meskipun ada kelapa tetapi hanya diperuntukkan bagi kebutuhan rumah tangga.

Status Desa Ciomas sebagai kawasan kon- servasi menyebabkan pola tanam yang dikembangkan tidak banyak variasinya. Hal ini disebabkan petani lebih fokus mengembangkan sektor jasa (wisata ziarah di Danau Panjalu). Sedangkan pola tanam di Desa Kalijaya dan Desa Kertaharja lebih variatif yang menandakan bahwa petani di kedua desa ini lebih terbuka dalam menerima teknologi dari luar khususnya silvikultur. Oleh karena itu, peluang perkembangan hutan di Desa Kalijaya dan Kertaharja lebih besar dibandingkan di Desa Ciomas.

\section{B. Analisis Faktor-Faktor Penentu dalam Pe- ningkatan Kondisi Sosial Ekonomi Petani}

Ekonomi petani sangat dinamis karena dipengaruhi oleh beberapa faktor seperti berikut:

1) umur petani: secara fisik petani usia muda cenderung lebih produktif dalam mengelola hutan rakyat dibandingkan petani yang 
usianya lebih tua.

2) Tingkat pendidikan: semakin tinggi tingkat pendidikan petani, semakin tinggi daya kreativitas dan inovasinya dalam mengembangkan hutan rakyat.

3) Jumlah tanggungan keluarga: sebagai bisnis berbasis keluarga, kegiatan pada pengembangan hutan rakyat dipengaruhi oleh banyaknya anggota keluarga,

4) Lama tinggal di desa: semakin lama petani tinggal di desa, semakin besar peluang menemukan teknologi pengembangan hutan rakyat yang sesuai di daerah itu,

5) Total pendapatan: pengembangan hutan rakyat dipengaruhi oleh besarnya modal yang dimiliki petani. Oleh karena itu pendapatan total petani diduga mempengaruhi perkembangan hutan rakyat,

6) Penguasaan lahan: upaya peningkatan pendapatan petani disiasati salah satunya dengan memperluas lahan garapan

Berdasarkan hasil perhitungan menggunakan garis kemiskinan Sajogyo (1988) dalam Simanjuntak (2007) diketahui bahwa petani hutan rakyat di semua lokasi penelitian dihasilkan kondisi petaninya berada di atas garis kemiskin, selanjutnya untuk mengetahui faktor apa saja yang dapat meningkatkan kondisi sosial ekonomi petani dihitung dengan menggunakan uji Chi-square dengan tingkat kepercayaan 95\%

Tabel(Table) 12. Hasil Uji Chi-Square Faktor-faktor Penentu yang Mempengaruhi Peningkatan Ekonomi Petani Hutan Rakyat Di Kabupaten Ciamis. (Chi-Square Test of key factors influencing the farmer's economic improvement in Ciamis District).

\begin{tabular}{|c|c|c|c|c|c|c|c|}
\hline \multirow[b]{2}{*}{ No } & \multirow[b]{2}{*}{ Faktor (Factors) } & \multicolumn{2}{|c|}{$\begin{array}{l}\text { Desa Ciomas } \\
\text { (Ciomas Village) }\end{array}$} & \multicolumn{2}{|c|}{$\begin{array}{c}\text { Desa Kalijaya } \\
\text { (Kalijaya Village) }\end{array}$} & \multicolumn{2}{|c|}{$\begin{array}{c}\text { Desa Kertaharja } \\
\text { (Kertaharja Village) }\end{array}$} \\
\hline & & $\begin{array}{l}\text { Chi- } \\
\text { Square } \\
\text { hitung } \\
\text { (Count) }\end{array}$ & $\begin{array}{l}\text { Chi- } \\
\text { Square } \\
\text { Tabel } \\
\text { (Table) }\end{array}$ & $\begin{array}{l}\text { Chi- } \\
\text { Square } \\
\text { hitung } \\
\text { (Count) }\end{array}$ & $\begin{array}{c}\text { Chi- } \\
\text { Square } \\
\text { Tabel } \\
\text { (Table) }\end{array}$ & $\begin{array}{l}\text { Chi- } \\
\text { Square } \\
\text { hitung } \\
\text { (Count) }\end{array}$ & $\begin{array}{c}\text { Chi- } \\
\text { Square } \\
\text { Tabel } \\
\text { (Table) }\end{array}$ \\
\hline 1 & Umur & $10,800^{*}$ & 22,362 & 3,800 & 22,362 & 2,100 & 26,296 \\
\hline 2 & Tingkat Pendidikan & 12,500 & 9,488 & $35,300^{*}$ & 12,592 & $31,500^{*}$ & 9,488 \\
\hline 3 & $\begin{array}{l}\text { Jumlah tanggungan } \\
\text { keluarga }\end{array}$ & 5,000 & 9,488 & $16,000^{*}$ & 9,488 & 12,400 & 11,070 \\
\hline 4 & Lama tinggal di desa & 7,000 & 23,685 & 4,000 & 24,996 & 5,500 & 23,685 \\
\hline 5 & Total Pendapatan & 0,000 & 30,144 & 0,000 & 30,144 & 0,000 & 30,144 \\
\hline 6 & Pengusaan lahan & 0,900 & 28,869 & 0,000 & 30,144 & 0,000 & 30,144 \\
\hline
\end{tabular}

Sumber: Diolah dari data primer 2010 (Sources: Analized from the primary data, 2010)

Keterangan : *=berhubungan nyata (remarks :(significantly correlated)

(alpha 0,05), seperti diperlihatkan oleh Tabel 12.

Tingkat pendidikan petani di Desa Ciomas bukan menjadi faktor penentu terhadap peningkatan ekonomi petani dengan hasil uji Chi-square tidak nyata pada tingat kepercayaan $95 \%$. Hal ini disebabkan pendapatan utama yang mempengaruhi kondisi ekonomi petani bukan dari pengelolaan hutan, tetapi dari jasa hutan seperti berjualan cidera mata, jasa ojeg, usaha warung yang tidak membutuhkan skill tertentu (Tabel 5). Untuk jenis pekerjaan seperti itu, tingkat kematangan petani (umur) dalam menawarkan suatu produk lebih berpengaruh, sehingga umur petani di Desa Ciomas menjadi faktor penentu peningkatan kondisi ekonomi rumah tangga petani.

Kondisi berbeda ditunjukkan oleh petani di Desa Kalijaya dan Desa Kertaharja dimana pendapatan utama yang mempengaruhi kondisi sosial-ekonomi petani berasal dari pengelolaan hutan rakyat. Tinggi rendahnya tingkat pendidikan petani mempengaruhi pendapatan petani dari mengelola hutan rakyat sebagai pengaruh dari tinggi rendahnya kemampuan mengadopsi teknologi dan mengolah informasi terkait dengan pengelolaan hutan rakyat. Hal senada dilaporkan oleh Hamid et al. (2011) bahwa ada hubungan nyata antara pendidikan dengan kondisi sosial ekonomi pasca berakhirnya HPH PT. Siak Raya Timber di Desa Segati Kecamatan Langgam 
Kabupaten Pelalawan Provinsi Riau.

Pengelolaan hutan rakyat juga tergantung pada banyaknya tenaga kerja yang tersedia yang biasanya berasal dari anggota keluarga. Petani Desa Kalijaya telah memutuskan untuk meningkatkan pendapatan dari perluasan lahan hutan meskipun sebagian melalui sewa. Hal ini berarti semakin membutuhkan banyak tenaga kerja. Oleh karena itu, jumlah tanggungan keluarga menjadi faktor penentu bagi peningkatan kondisi sosial-ekonomi di Desa Kalijaya. Kondisi ini tidak berlaku bagi sektor jasa, sehingga kondisi sosial ekonomi petani di Desa Ciomas tidak ditentukan oleh faktor jumlah tanggungan keluarga. Hal ini mirip dengan yang terjadi di Desa Kertaharja dimana karena faktor geografis, sebagian anggota keluarga sering melakukan migrasi ke desa-desa di Kabupaten Cilacap (Jawa Tengah) untuk keperluan lain sehingga banyaknya anggota keluarga tidak mempengaruhi kondisi ekonomi petani hutan rakyat di desa ini.

\section{KESIMPULAN DAN SARAN}

\section{A. Kesimpulan}

1. Kondisi sosial ekonomi petani hutan rakyat yang dapat mempengaruhi perkembangan pembangunan hutan rakyat di Kabupaten Ciamis adalah :

a. Usia produktif petani: Petani di tiga lokasi penelitian mayoritas tergolong pada usia produktif menengah dan tua yaitu antara 40-59 tahun.

b. Tingkat pendidikan: Rata-rata tingkat pendidikan petani hanya setara SMP kelas 1-2 (atau lama pendidikan 7-8 tahun).

c. Sumber dan kontribusi pendapatan : Sumber pendapatan keluarga petani bervariasi yaitu dari usaha hutan rakyat, jasa, keluarga, sawah, hewan ternak dan kolam ikan. Kegiatan hutan rakyat memberikan kontribusi paling besar bagi keluarga petani hutan rakyat di Desa Kalijaya dan Kertaharja, masing-masing sebesar Rp 11.180.002/tahun (35,08\%) dan Rp 8.956.809/tahun (42,81\%). Sedangkan di Desa Ciomas, pendapatan keluarga terbesar diperoleh dari sektor jasa yaitu Rp 9.334.000/tahun (44,49\%), sementara pendapatan dari hutan rakyat di desa ini sebesar Rp 7.493.232/tahun $(35,72 \%)$.

d. Distribusi pendapatan: Surplus pendapatan petani didapati di seluruh lokasi penelitian, namun distribusinya masih timpang. Tingkat ketimpangan tinggi terjadi di Desa Ciomas dengan nilai koefisien gini sebesar 0,56 , sedangkan tingkat ketimpangan sedang terjadi di Desa Kalijaya dan Kertaharja dengan nilai koefisien gini berturut-turut 0,47 dan 0,47. Berdasarkan perhitungan garis kemiskinan Sajogyo, kesejahteraan petani di lokasi penelitian sudah berada di atas garis kemiskinan, dengan pendapatan perkapita sebesar Rp 20.980.582/tahun (Desa Ciomas), Rp 31.873.527/tahun (Desa Kalijaya), dan Rp 24.536.559/tahun (Desa Kertaharja).

e. Rata-rata penguasaan lahan: Penguasaan lahan oleh petani di Desa Ciomas rata-rata seluas 0,94 ha, di Desa Kalijaya seluas 2,33 ha, dan di Desa Kertaharja seluas 0,96 ha. Mayoritas lahan dipergunakan untuk usaha hutan rakyat masing-masing 0,7737 ha $(82,07 \%)$ untuk Desa Ciomas, 2,078 ha $(89,33 \%)$ untuk Desa Kalijaya dan 0,7271 ha $(76,02 \%)$ untuk Desa Kertaharja.

f. Pola tanam hutan rakyat: Pola tanam di seluruh lokasi penelitian memiliki kesamaan yaitu campuran antara tanaman kehutanan, tanaman perkebunan, tanaman pangan, tanaman buah dan tanaman obat. Perbedaan terletak pada jenis tanaman penyusun pola tanam tersebut. Terdapat beberapa jenis tanaman yang dominan di suatu daerah tetapi tidak dikembangkan di daerah lain.

2. Faktor-faktor yang dapat meningkatkan kondisi sosial ekonomi petani hutan rakyat di Kabupaten Ciamis adalah:

a. Umur petani untuk Desa Ciomas

b. Tingkat pendidikan petani dan jumlah tanggungan keluarga untuk Desa Kalijaya

c. Tingkat pendidikan petani untuk Desa Kertaharja.

\section{B. Saran}

Untuk meningkatan kualitas pembangunan hutan rakyat, perlu ditingkatkan kondisi sosial ekonomi petaninya, terutama pendidikan. Pemerintah Daerah Kabupaten Ciamis disarankan bisa mempercepat perbaikan kondisi sosial ekonomi petani dengan memprioritaskan revitalisasi sarana dan prasarana produksi di Kabupaten Ciamis meliputi hal-hal: perbaikan jalan, akses terhadap informasi usaha tani dan sumber permodalan, penyediaan dan perluasan pasar, dan penguatan kelembagaan. 


\section{DAFTAR PUSTAKA}

Achmad, B. \& Diniyati, D. (2012). Luas unit usaha agroforestry dan populasi pohon sengon (Falcataria moluccana) pada Hutan Rakyat di Kabupaten Ciamis. Hlm 390-395. Prosiding. Seminar Nasional Agroforestri III. Pembaharuan Agroforestri Indonesia: Benteng Terakhir Kelestarian, Ketahanan Pangan, Kesehatan dan Kemakmuran. Kerjasama Balai Penelitian Teknologi Agroforestry, Fakultas Kehutanan dan Kebun Pendidikan Penelitian dan Pengembangan Pertanian (KP4) UGM dan Indonesia Networks for Agroforestry Education (INAFE).

Achmad, B. \& Ris. H.P. (2014). Peluang adopsi system agroforestry dan kontribusi ekonomi pada berbagai pola tanam Hutan Rakyat di Kabupaten Ciamis. Jurnal Bumi Lestari Vol 14 No.1.

Dewi, I.N. \& Iwanuddin. (2005). Kajian sosial ekonomi budaya dan persepsi masyarakat sekitar Danau Tempe (Socio economic cultural Study and perception of community around The tempe take). Jurnal Penelitian Sosial Dan Ekonomi Kehutanan. Volume 2 Nomor 3, September Tahun 2005. Hlm. 245 - 258. Pusat Penelitian dan Pengembangan Sosial Budaya Dan Ekonomi Kahutanan.Badan Penelitian dan Pengembangan Kehutanan. Departemen Kehutanan. Bogor

Eliana, N. \& Ratina R. (2006). Faktor-faktor yang mempengaruhi curahan waktu kerja wanita pada PT Agricinal Kelurahan Bentuas Kecamatan Palaran Kota SamarindaAkses tanggal 1Oktober 2012 dari:.Http://isjd. pdii.lipi.go.id/admin/jurnal/4207814.pdf.

Hamid, R., Zulkarnaini \& Saam. Z. (2011). Analisis sosial ekonomi masyarakat desa hutan pasca kegiatan HPH PT. Siak Raya Timber Di Kabupaten Pelalawan, Provinsi Riau. Akses tanggal 27 Februari 2014,dari:http://ejo urnal.unri.ac.id/index.php/JIL/article/.../351/3 45.

Haryanti, N., Paimin \& Sukresno. (2005). Kondisis osial masyarakat Sub DAS Merawu dan Sub DAS Batang Bungo (Social condition of community at Merawu and Batang Bengo Sub Watersheds). Jurnal Penelitian Sosial dan Ekonomi Kehutanan. Volume 2 Nomor 3. Hlm $231-244$.

Irawanti, S. (2006). Kajian sosial ekonomi dan kelembagaan Taman Nasional BantimurungBulusaraung di Sulawesi Selatan. Info Sosial Ekonomi.6(1):39- 57.
Khususiyah, N., Buana, Y. \& Suyanto. (2010). Hutan Kemasyarakatan (HKm): Upaya meningkatkan kesejahteraan dan pemerataan pendapatan petani miskin di sekitar hutan. Brief No. 06 Policy Analysis Unit Juni 2010. World Agroforestry Centre. Bogor

Mairi, K. (2005). Studi sosial budaya masyarakat Adat Toraja dalam rangka pelestarian sumber daya hutan (Socio-Cultural study of Toraja Custume Society in relation with sustainability of forest resources). Jurnal Penelitian Sosial dan Ekonomi Kehutanan, 2 (3): 245 - 258.

Badan Litbang Kehutanan dan Perkebunan. (2000). Pedoman survei sosial ekonomi kehutanan Indonesia. Pusat Penelitian Sosial Ekonomi Kehutanan dan Perkebunan. Badan Litbang Kehutanan dan Perkebunan. Departemen Kehutanan dan Perkebunan.

Pujianto, E. (2008). Analisis penyerapan dan curahan tenaga kerja keluarga pada usaha peternakan domba (Studi kasus Di Desa Cibunian Kecamatan Pamijahan dan Desa Cigudeg Kecamatan Cigudeg Kabupaten Bogor. Skripsi.Tidak diterbitkan. Program Studi Sosial Ekonomi Peternakan Fakultas Peternakan. Institut Pertanian Bogor.

Tanjung, D.R. (2012). Pendidikan untuk Kesejahteraan. Akses tanggal 6 November 2012.http://dodirtanjung.blogspot.com/2009/0 2/pendidikan-berkualitas-adalah-solusi.html. Diakses pada tanggal 6 November 2012.

Sani, Arsad, La Ode Santosa, K. A. \& Ngadiyono, N. (2010). Curahan Tenaga Kerja Keluarga Transmigran dan Lokal pada Pemeliharaan Sapi Potong di Kabupaten Konawe Selatan, Sulawesi Tenggara. Buletin Peternakan, Vol. 34 (3): 194-201.

Sanudin \& Antoko, B.S. (2007). Kajian Sosial Ekonomi Masyarakat di DAS Asahan, Sumatera Utara. (The Study on SocioEconomic of Communities in Asahan Watershed, North Sumatra). Jurnal Penelitian Sosial dan Ekonomi Kehutanan, 4 (4): 355365. 
Simanjuntak, T. (2007). Analisis curahan tenaga kerja dan pendapatan petani dafed pada usahatani padi sawah. (Studi Kasus : Desa Karang Anyer, Kecamatan Gunung Maligas, Kabupaten Simalungun). Skripsi.Tidak diterbitkan. Departemen Sosial Ekonomi Pertanian. Fakultas Pertanian. Universitas Sumatera Utara. Medan.

Sudaryanto, T., Saliem, H.P. \& Pasaribu, S. (1981). Pola penggunaan tenaga kerja di pedesaan: studi kasus di empat Desa Kabupaten Kudus dan Klaten, Jawa Tengah. Pusat Penelitian Agro Ekonomi. Badan Penelitian dan Pengembangan Pertanian. Departemen Pertanian.

Supriadi, H. \& Saliem, P.H. (2006). Kondisi sosial ekonomi dan implikasi kebijakan terhadap upaya pengembangan pertanian di Lahan Kering Marginal. Akses tanggal 24 September 2012, dari:Http://ntb.litbang.deptan.go. $\mathrm{id} / \mathrm{ind} / 2006 / \mathrm{SP} /$ kondisisosial.doc.
Susilowati, S.H \& Suhaeti, R.N.(2012). Dinamika Ekonomi Pedesaan di Jawa Barat. Akses tanggal 28 Juni 2012,dari:Http://pus taka.litbang.deptan.go.id/publikasi/wr241025. pdf.

Susilowati, S.H. \& Maulana, M.(2012). Luas Lahan Usahatani dan Kesejahteraan Petani: Eksistensi Petani Gurem dan Urgensi Kebijakan Reforma Agraria. Akses tanggal 5 November 2012 , dari:http://pse. litbang.deptan.go.id/ind/index.php?option $=$ co $\mathrm{m}$ - content\&task $=$ view\&id $=849 \&$ Itemid $=60$.

Wahyono, T. (2002). 36 Jam Belajar Komputer. Analisis Data Statistik dengan SPSS 14. Hlm. 201 - 207.Jakarta: PT. Elex Media Kom putindo. 